project was characterized with the rejection of the idea of the firm structure that is based on the binary oppositions and the idea of the strict determinism. In the works they call not to be in love with the state power and to deindividualize; they also suggested the idea of inclusion, t.e. the increase of the extent of citizens' involvement in the life of society.

\title{
Bibliography:
}

1. Пригожин И., Стенгерс И. Порядок из хаоса: Новый диалог человека с природой: Перс англ.- М.Прогресс, 1986. С. 275-386

2. Ж. Делез, ф. Гваттари Анти-Эдип: Капитализм и шизофрения / Пер. с фр. и послесл. Д. Кралечкина, науч. ред. В. Кузнецов.Екатеринбург.: У-Фактория, 2007. - 672 с.

3. Ж. Делез, Ф. Гваттари Тысяча плато: Капитализм и шизофрения / Пер. с фр. и послесл. Я. И. Свирского, науч. ред. В. Ю. Кузнецов. Екатеринбург, М.: У-Фактория, Астрель, 2010. - 895 с.

\section{DOI https://doi.org/10.30525/978-9934-26-117-6-5}

\section{ТВОРЧІСТЬ ЯК ВИЯВ СВОБОДИ ЛЮДИНИ}

\author{
Марасва У. М. \\ кандидат філософських наук, \\ дочент кафедри філософії \\ Державний вищий навчальний заклад \\ «Ужгородський національний університет» \\ м. Уэггород, Украӥна
}

Духовно-практичний досвід $є$ невід'ємною складовою розвитку будь-якого суспільства. Основною його ознакою є ідеальна фіксація у формах свідомості різних компонентів зв'язку людини і світу. В ідеальній формі він відображений у філософії та мистецтві як результат прояву духовної культури і втілений у продуктах діяльності та творчості. Тому через творчу діяльність цей зв'язок відображає потреби у самоздійсненні людини, забезпечуючи при цьому духовний зв'язок і спадковість суспільства.

Творчість як фундаментальна властивість людини $\epsilon$ проявом людської суб'єктивності. Тому вона завжди пов'язана із свободою людини, вираженням внутрішньої усвідомленості своєї свободи як індивідуального рівня самореалізації. Оскільки свобода є головною 
і необхідною умовою творчості, вона виступає основою творення культури, iї активним двигуном та рушійною силою. Свобода детермінує специфічні якості людської діяльності, межі ії залученості до соціальної дійсності, відтворення своєї власної ідентичності у процесі творчості.

Ознакою свободи є вільний суб'єкт - той, хто здатний панувати над світом природи і суспільства, діяти, перетворюючи реальність, втілюючи внутрішні потенції. «Людина, як суб'єкт розумної волі, підноситься над світом-об'єктом, виходить за його межі, перебуває «над» або відноситься до нього зовнішнім чином, відвойовуючи простір для панування своєї свободи - раціонально контрольованої діяльності, у тому числі щодо суспільної реальності» [1, с. 11], і в решті решт, досягаючи внутрішньої рівноваги, «гомеостазу», гармонії зі світом і з самим собою у процесі творчої діяльності. Тому творчість тут постає як мистецтво, що відтворює екзистенційну сутність людини та основну властивість ії свободи - необхідність творити.

Через творчість людина трансцендує від іiі фізичного буття до виходу за межі біологічного існування, втілюючи ії внутрішню свободу i автономність. [3] Вона є підставою для творення особистістю навколишньої дійсності, відображаючи свої особистісні, індивідуальні духовні запити. Тому творчість $є$ проявом екзистенційності людини, тоді як «не творчість» (за визначенням А. В. Смірнова) [4, с. 25] це прояв детермінізму, тобто наслідування певних законів.

В творчості проявляється внутрішній світ митця, його ідеї, що відображають сутнісні основи буття людини, її світогляду, моральних та естетичних уподобань, втілених у конкретних художніх образах, які є символічним виявом феноменологічної активності суб'єкта (творця). Через художній образ як прояв свідомості людини творець відображає власну суб'єктивну духовно-психічну реальність, відтворюючи ідеї, уявлення, образи, фіксовані в образно-символічному змісті. Вони $\epsilon$ проявом художньої діяльності митця. Втілюючи свою суб'єктивність в об'єктивно-реальних продуктах своєї діяльності, людина відтворює свій власний унікальних світ, зберігаючи свою ідентичність у світлі кон'юнктурних ситуацій, що постійно змінюються.

Однак, ця діяльність має двосторонній процес. 3 одного боку, вона постає як відтворення внутрішнього світу митця у всій багатоманітності його проявів, з іншого, - це сприйняття його творчості i, в результаті, прийняття чи неприйняття, інтерпретація слухачем, глядачем, споживачем основного задуму творця.

Під творцем розуміємо суб'єкта з його новими ідеями, креативним, однак, часто радикальними і незрозумілими загалу. Бути «на одній 
хвилі» 3 творцем - означає пропустити крізь себе його задум, побачити у художніх образах щось близьке і зрозуміле, дотичне для себе, злитися 3 творцем в одному духовному смисловому полі. Тому слушною $\epsilon$ думка Л. Газнюк про те, що саме через сприйняття твору мистецтва розкривається і реально функціонує унікальний художній світ, «згорнутий художником в акті створення твору мистецтва в його предметну (мальовничу, музичну, поетичну й т. п.) реальність, яка розгортається вже у внутрішньому світі суб'єкта сприйняття» [2]. Ця «співпричетність» реципієнта до творіння є реальним засобом життєвості художнього задуму i, як наслідок, живучої властивості мистецтва.

Однак, свобода тут виявляється як у «співпереживанні» задуму автора, так і у виявленні свободи вибору сприймаючого. При цьому, його інтерпретація може відрізнятися від самого задуму. Кожен суб'єкт накладає відбиток свого власного світогляду, життєвого світу і переживань. Тому інтерпретуючи символи і смисли, в уяві реципієнта з'являються інші образи, близькі за формою, і різні за змістом і семантичним навантаженням. Отже, свобода тут постає як вільне потрактування значень і смислів окремого суб’єкта, де кожен, долучаючись i пропускаючи крізь себе твори мистецтва, може під їх впливом сформувати свою власну внутрішню рефлексію.

\section{Література:}

1. Бистрицький Є. К. Пропедевтика поняття свободи. Проблеми сутності свободи: методологічні та соціальні виміри: Матеріали науково-теоретичної конферениії 26 жовтня 2007 р. К., 2007. С. 8-29.

2. Газнюк Л. М. Естетика: навч. посіб. для гуманітар. спец. К.: Кондор, 2011. 124 с.

3. Кримський С. Б. Заклики духовності XXI століття: (3 циклу щорічних пам'ятних лекцій імені А. Оленської-Петришин, 2002 р.) К.: Академія, 2003. 32 с.

4. Смирнов А. В. Творчество и логика: к вопросу о концептуализации границы между творческим и нетворческим. Философия творчества: материаль Всероссийской научной конференции, 8-9 апреля 2015 г., Институт философии РАН, г. Москва. М.: ИИнтелл, 2015. С. 25-30. 